\title{
The Transient Tracers in the Ocean (TTO) Program: The North Atlantic Study, 1981; The Tropical Atlantic Study, 1983
}

\author{
PETER G. BreWER \\ Woods Hole Oceanographic Institution, Massachusetts \\ JORGE L. SARMIENTO \\ Geophysical Fluid Dynamics Program, Princeton University, New Jersey \\ William M. SMETHIE, JR. \\ Lamont-Doherty Geological Observatory of Columbia University, Palisades, New York
}

The scientific papers here collected result from the Transient Tracers in the Ocean (TTO) program. The two parts of this major geochemical and physical oceanographic expedition took place in the North Atlantic Ocean in 1981 and in the Tropical Atlantic in 1983 on the research vessel Knorr of the Woods Hole Oceanographic Institution.

The expeditions, sponsored by the National Science Foundation and the U.S. Department of Energy (North Atlantic only), were designed to observe the passage of man-made geochemical tracers into the interior of the ocean. The foundations for such an experiment were laid in the 1972-1978 GEOSECS program. Here, for the first time, a systematic survey revealed the penetration into the thermocline and deep ocean of the products of man's military/industrial activities, principally tritium and carbon-14 resulting from atmospheric testing of nuclear weapons, which terminated with the nuclear test ban treaty in 1962 .

This labeling of the surface waters of the world's oceans provides us with a marvelous opportunity to observe the evolution of such a signal, for the passage of these tracers documents as nothing else can the manner and time scale of ocean mixing and provides a fundamental calibration for models of ocean circulation.

In the northern North Atlantic deep wintertime, convection has transported these tracers to great depth. Spilling out through the straits and over the sills connecting the northern basins with the open ocean, these chemical species have begun their global deep-ocean tour.

Inspection of the 1972 GEOSECS Atlantic results caused ocean scientists to ask important questions. The tritium signal elegantly measured by Ostlund and colleagues vividly revealed penetration into the ocean during an approximate 10-year (1962-1972) period. What fraction of the ocean would be labeled during a 20-year period? The GEOSECS data were limited in the North Atlantic to a single two-dimensional section. What was the three-dimensional picture? Heightened concern over ocean uptake of the rising levels of atmospheric $\mathrm{CO}_{2}$ led to further questions. How could tracers be used to calibrate models of ocean $\mathrm{CO}_{2}$ uptake? Were the necessary fundamental measurements of ocean $\mathrm{CO}_{2}$ properties in place? What important tools were missing?

\section{Copyright 1985 by the American Geophysical Union.}

Paper number 5C0209.

$0148 / 0227 / 85 / 005 C-0209 \$ 02.00$
In 1978 a group of scientists met to form a steering committee and to tackle these questions. (TTO Steering Committee: H. G. Ostlund, P. G. Brewer, W. S. Broecker, W. J. Jenkins, J. L. Reid, C. G. Rooth, T. Takahashi, R. T. Williams (North Atlantic); J. L. Sarmiento, W. S. Broecker, T. Takahashi, C. G. Rooth, W. M. Smethie, R. T. Williams (Tropical Atlantic)). It was at once abundantly clear that a powerful opportunity existed. The use of ocean tritium measurements had been greatly enhanced through the development of ultrasensitive mass-spectrometric techniques and through the use of tritium-helium dating. Ocean $\mathrm{CO}_{2}$ data were not available in the northern North Atlantic from the GEOSECS program and therefore could not be coupled with the tracer information. Important advances in theory and in experimental practice now made this possible.

New tools were found in the capability to measure the chlorofluoromethanes ("freons") and ${ }^{85} \mathrm{Kr}$, which are released into the atmosphere by man, and the rare, naturally occurring radioactive isotope ${ }^{39} \mathrm{Ar}$. Further, the radioactive waste products ${ }^{137} \mathrm{Cs}$ and ${ }^{134} \mathrm{Cs}$, discharged from European nuclear fuel reprocessing plants principally after 1973, had now reached the North Atlantic Deep Water source regions and were providing an important tracer signal.

The ability to carry out extensive field operations depended greatly upon the availability of a talented, energetic, and resourceful logistics team. The sudden death of a A. E. Bainbridge in 1979 shocked and saddened those who knew and honored him as a leader in this field. Fortunately, R. T. Williams rose to the occasion and with remarkable skill and quiet professionalism was able to create a smoothly functioning machine out of disparate parts.

A test cruise in 1980 to survey the "tritium front" and to assess the newly demanding techniques took place. Finally, on April 1, 1981, the Knorr left Woods Hole on a 9-month, $20,512 \mathrm{~km}$ (12,745-mile) journey for the North Atlantic Study. During the $\mathbf{2 0 0}$ days that followed, 250 hydrographic stations were occupied, and approximately 6000 samples were collected for tritium analysis, 3000 samples for ${ }^{3} \mathrm{He}$ analysis, 1000 samples for ${ }^{14} \mathrm{C}$ and ${ }^{228} \mathrm{Ra}$ analysis, 400 samples for ${ }^{85} \mathrm{Kr}$ analysis, 200 samples for $\mathrm{Cs}$ isotope analysis, and 25 samples for ${ }^{39} \mathrm{Ar}$ analysis. More than 5000 measurements of ocean $\mathrm{CO}_{2}$ properties were made, together with salinity, oxygen, and nutrient determinations. Remarkably, during those 200 days, not a single piece of equipment was lost, nor was any person injured, nor a deadline missed. An extraordinary achievement.

International cooperation is vital in such a large under- 


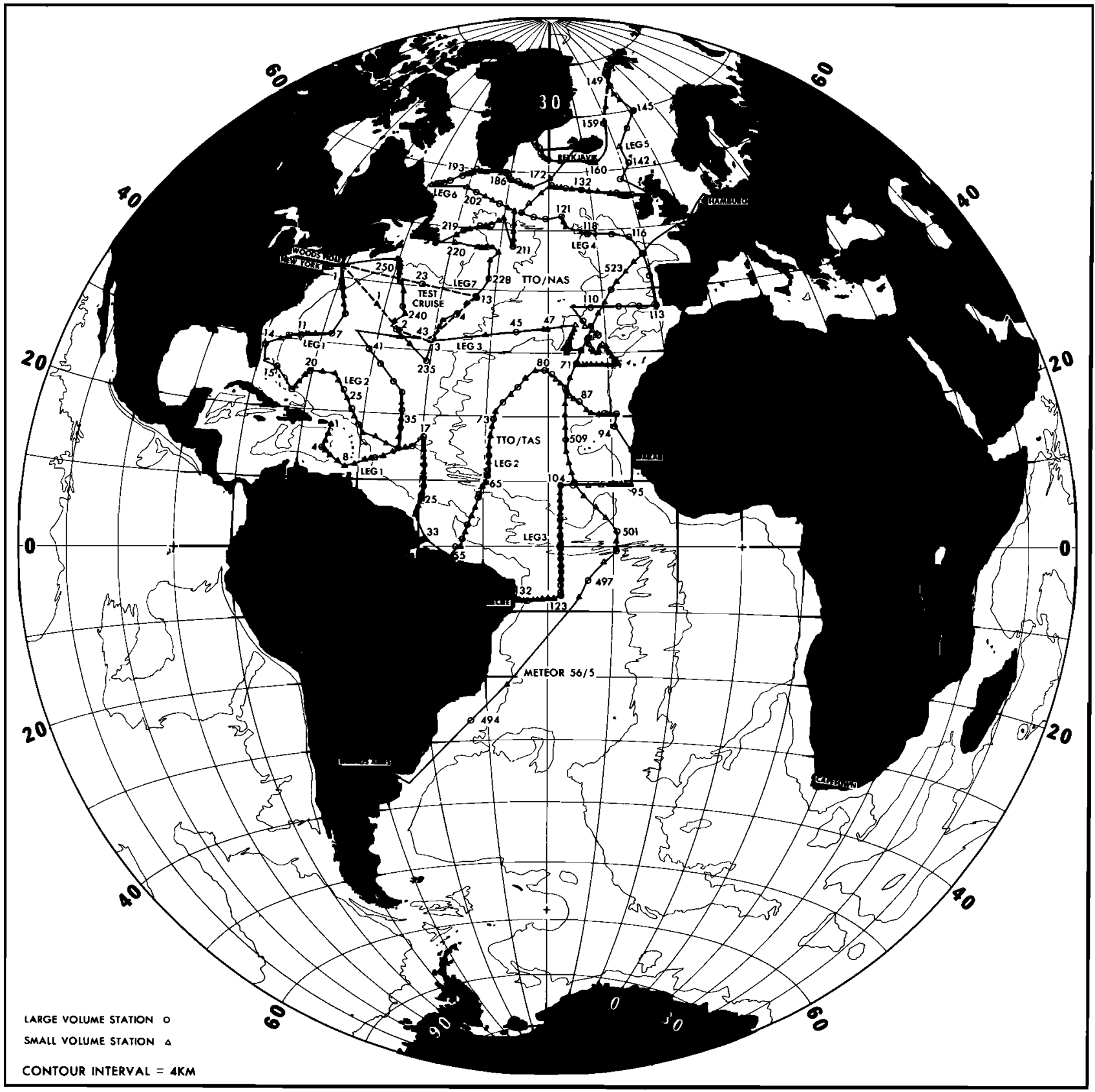

Fig. 1. Cruise track and station locations for the Transient Tracers in the Ocean program.

taking. Crucial were the efforts of the German-U.S. team, led by W. Roether on the Meteor, in constructing an eastern Atlantic tracer section in 1981. The extraordinary talents of Swiss scientists in the area of low-level counting were critical in implementing the ${ }^{85} \mathrm{Kr}$ and ${ }^{39} \mathrm{Ar}$ studies.

In 1983 the work continued. Inevitable constraints on time and effort in the North Atlantic Study had curtailed the region of study. Analyses of the oceanic tritium inventory showed that further coverage was needed so as to encompass the tropical ocean boundaries. Again the expedition team rose to the occasion. The Knorr left San Juan, Puerto Rico, on December 1, 1982, for its 3-month journey in the tropical Atlantic that ended in Recife, Brazil; 132 hydrographic stations were occupied with double that number of XBT profiles. Between 25 and 40 measurements of ocean $\mathrm{CO}_{2}$ properties, salinity, oxygen, nutrients, and chlorofluoromethanes were made at each station. More than 400 samples were obtained for ${ }^{14} \mathrm{C}$ and ${ }^{228} \mathrm{Ra}, 100$ samples for ${ }^{85} \mathrm{Kr}$, nine samples for ${ }^{39} \mathrm{Ar}$, and approximately 3000 samples for tritium $/{ }^{3} \mathrm{He}$ analysis. The ocean work was complemented by a series of important geochemical measurements in the Amazon estuary at the end of the first leg of the expedition.

The cruise tracks for these expeditions are to be found in Figure 1. The scientists directing the various expedition legs (an asterisk denoting chief scientist) were as follows:

\section{North Atlantic Study, 1981}

Leg 1 (Woods Hole to Freeport): P. G. Brewer*, R. T. Williams.

Leg 2 (Freeport to Bermuda): J. L. Sarmiento*, R. T. Williams.

Leg 3 ( Bermuda to Azores): L. Armi*. 
TABLE 1. Measurements Made and Responsible Investigators for TTO Analysis and Data Sets

\begin{tabular}{|c|c|}
\hline Measurement & Investigator (Expedition) \\
\hline CTD & PACODF $^{*}$ (NAS, TAS) \\
\hline Temperature, salinity & PACODF* (NAS, TAS) \\
\hline Nutrients & PACODF* (NAS, TAS) \\
\hline $\begin{array}{l}\text { Alkalinity and } \\
\text { total carbon dioxide }\end{array}$ & $\begin{array}{l}\text { P. G. Brewer (NAS) } \\
\text { PACODF* (NAS, TAS) } \\
\text { C. D. Keeling (NAS, TAS) }\end{array}$ \\
\hline$p \mathrm{CO}_{2}$ & $\begin{array}{l}\text { T. Takahashi (NAS, TAS) } \\
\text { D. Chipman (NAS, TAS) }\end{array}$ \\
\hline Tritium & $\begin{array}{l}\text { H. G. Ostlund (NAS, TÁS) } \\
\text { W. J. Jenkins (NAS, TAS) }\end{array}$ \\
\hline${ }^{3} \mathrm{He}$ & W. J. Jenkins (NAS, TAS) \\
\hline Chlorofluoromethanes & $\begin{array}{l}\text { R. Gammon (leg } 7 \text { NAS, TAS) } \\
\text { R. F. Weiss (TAS) }\end{array}$ \\
\hline${ }^{14} \mathrm{C}$ & $\begin{array}{l}\text { H. G. Ostlund (NAS, TAS) } \\
\text { W. Roether (TAS) }\end{array}$ \\
\hline${ }^{85} \mathrm{Kr}$ & $\begin{array}{l}\text { W. M. Smethie (NAS, TAS) } \\
\text { W. S. Broecker (NAS, TAS) }\end{array}$ \\
\hline${ }^{228} \mathbf{R a}$ & $\begin{array}{l}\text { J. L. Sarmiento (NAS, TAS) } \\
\text { R. Key (NAS, TAS) } \\
\text { W. Moore (NAS) }\end{array}$ \\
\hline${ }^{39} \mathrm{Ar}$ & $\begin{array}{l}\text { H. Loosli (NAS, TAS) } \\
\text { W. M. Smethie (NAS, TAS) }\end{array}$ \\
\hline $\begin{array}{l}{ }^{137} \mathrm{Cs},{ }^{134} \mathrm{Cs} \\
{ }^{222} \mathrm{Rn}\end{array}$ & $\begin{array}{l}\text { H. D. Livingston (NAS legs 5, 6) } \\
\text { W. M. Smethie (NAS, TAS) }\end{array}$ \\
\hline Underway $p \mathrm{CO}_{2}, p \mathrm{CH}_{4}, p \mathrm{~N}_{2} \mathrm{O}$ & R. F. Weiss (NAS, TAS) \\
\hline
\end{tabular}

*PACODF is the Physical and Chemical Oceanographic Data Facility of Scripps Institution of Oceanography, it was directed by $R$. $T$. Williams for NAS and TAS.

Leg 4 (Azores to Glasgow): W. S. Broecker*, C. G. Rooth. Leg 5 (Glasglow to Reykjavik): T. Takahashi*, J. H. Swift. Leg 6 (Reykjavik to St. Johns): W. J. Jenkins*, P. B. Rhines. Leg 7 (St. Johns to Woods Hole): P. G. Brewer*, W. M. Smethie.
Tropical Atlantic Study, 1983

Leg 1 (Pureto Rico to Belem): J. L. Sarmiento*, W. M. Smethie, P. B. Rhines.

Leg 2 (Belem to Dakar): C. G. Rooth*, R. M. Key.

Leg 3 (Dakar to Recife): T. Takahashi*, C. Collins.

The measurements made and investigators responsible for these measurements are given in Table 1 .

Only a fraction of the scientific results of such an experiment can be brought together here. The results, the techniques developed, and the insights gained will influence ocean scientists for years to come.

The immediate shipboard hydrographic and $\mathrm{CO}_{2}$ chemistry data were available in leg reports published shortly after the cruise. Magnetic tapes containing the hydrographic, nutrient, and $\mathrm{CO}_{2}$ data have been deposited with the Carbon Dioxide Information Center, Oak Ridge, Tennessee, and the National Oceanographic Data Center.

This collection of papers herein presents the first major published results of the TTO program. Since the GEOSECS program was a precursor of the TTO program, it is natural that some papers are based on both GEOSECS and TTO data. In addition to the papers published in this issue of JGR-Oceans, more papers will be published in a following issue. All of these papers will be available in a combined reprint. Finally, we use this opportunity to thank the participants in, and sponsors of, this substantial and important program.

P. G. Brewer, Woods Hole Oceanographic Institution, Woods Hole, MA 02543.

J. L. Sarmiento, Geophysical Fluid Dynamics Program, Princeton University, Princeton, NJ 08540.

W. M. Smethie, Jr., Lamont-Doherty Geological Observatory of Columbia University, Palisades, NY 10964.

(Received March 8, 1985; accepted March 9, 1985.) 